\title{
PENGARUH ROA, NPM, DAN EPS TERHADAP HARGA SAHAM PADA PERUSAHAAN SUBSEKTOR PERKEBUNAN YANG TERDAFTAR DI BEI
}

\author{
Dian Wulan Sari ${ }^{1}$, Suyadi $^{2}$, Eri Triharyati ${ }^{3}$, Fitria $^{4}$, Erwandy Irsal $^{5}$ \\ 1, 2, 3, 4, 5 Fakultas Ekonomi dan Bisnis, Universitas Bina Insan \\ Email: dian wulansari@univbinainsan.ac.id, suyadi@univbinainsan.ac.id, \\ eri_triharyati@univbinainsan.ac.id, fitria@univbinainsan.ac.id, erwandy.irsal@gmail.com
}

\begin{abstract}
ABSTRAK
Penelitian ini dilakukan untuk mengetahui pengaruh ROA, NPM, dan EPS terhadap harga saham pada perusahaan subsektor perkebunan periode tahun 2015 - 2017. Permasalahannya adalah terjadinya penurunan harga saham dan rasio perusahaan subsektor perkebunan disaat indeks harga saham gabungan menunjukkan kenaikan yang konsisten. Penelitian ini merupakan penelitian kuantitatif dengan tiga variabel bebas (X) dan satu variabel terikat (Y). Pengumpulan data menggunakan metode dokumentasi. Berdasarkan hasil analisis data menggunakan SPSS 25 maka dapat diambil kesimpulan bahwa : 1)Secara parsial Return On Asset $\left(\mathrm{X}_{1}\right)$ berpengaruh tidak signifikan terhadap Harga Saham (Y). 2)Secara parsial Net Profit Margin $\left(\mathrm{X}_{2}\right)$ berpengaruh tidak signifikan terhadap Harga Saham (Y). 3)Secara parsial Earning Per Share $\left(\mathrm{X}_{3}\right)$ berpengaruh signifikan terhadap Harga Saham (Y). 4)Secara simultan Return On Asset ( $\left.\mathrm{X}_{1}\right)$, Net Profit Margin $\left(\mathrm{X}_{2}\right)$, Earning Per Share $\left(\mathrm{X}_{3}\right)$ bengaruh positif dan signifikan terhadap Harga Saham (Y). Dapat disimpulkan bahwa secara parsial tidak terdapat pengaruh yang signifikan antara Return On Asset $\left(\mathrm{X}_{1}\right)$ dan Net Profit Margin $\left(\mathrm{X}_{2}\right)$ terhadap Harga Saham (Y), secara parsial terdapat pengaruh signifikan antara Net Profit Margin $\left(\mathrm{X}_{2}\right)$ terhadap Harga Saham (Y) dan secara simultan terdapat pengaruh positif dan signifikan antara Return On Asset (ROA) $\left(\mathrm{X}_{1}\right)$, Net Profit Margin (NPM) $\left(\mathrm{X}_{2}\right)$, Earning Per Share (EPS) $\left(\mathrm{X}_{3}\right)$ terhadap Harga Saham (Y).
\end{abstract}

Kata Kunci : Return On Asset (ROA), Net Profit Margin (NPM), Earning Per Share (EPS) dan Harga Saham

\section{ABSTRACT}

This research was conducted to determine the effect of ROA, NPM and EPS on stock prices in plantation sub-sector companies for the period 2015-2017. The problem is the decline in share prices and the ratio of companies in the plantation subsector when the composite stock price index shows a consistent increase. This research is a quantitative study with three independent variables (X) and one dependent variable (Y). Data collection using the documentation method. Based on the results of data analysis using SPSS 25, it can be concluded that: 1) Partially, Return on Assets (X1) has no significant effect on stock prices (Y). 2) Partially Net Profit Margin (X2) has no significant effect on Stock Price (Y). 3) Partially Earning Per Share (X3) has a significant effect on Stock Price (Y). 4) Simultaneously, Return On Asset (X1), Net Profit Margin (X2), Earning Per Share (X3) have a positive and significant effect on Stock Prices (Y). It can be concluded that partially there is no significant effect between Return On Assets (X1) and Net Profit Margin (X2) on Stock Prices (Y), partially there is a significant influence between Net Profit Margin (X2) on 


\section{A JURNAL AKUNTANSI, KEUANGAN, DAN TEKNOLOGI INFORMASI \\ AKUNTANSI}

Stock Prices (Y) and Simultaneously there is a positive and significant influence between Return On Asset (ROA) (X1), Net Profit Margin (NPM) (X2), Earning Per Share (EPS) (X3) on Stock Price (Y).

\section{Keywords: Return On Asset (ROA), Net Profit Margin (NPM), Earning Per Share (EPS) and Stock Price}

\section{PENDAHULUAN}

Pasar modal dapat kita gambarkan sebagai tempat perdagangan atau diperjualbelikannya modal berupa hak kepemilikan perusahaan dan surat pernyataan hutang perusahaan (obligasi). Seorang investor yang akan menanamkan investasinya, maka harus cermat dan tepat dalam memilih suatu perusahaan. Seorang investor akan memilih menanamkan modalnya kepada perusahaan yang dapat menghasilkan keuntungan semaksimal mungkin dan memiliki resiko yang sekecil mungkin, sehingga investor tersebut akan mendapatkan untung yang besar. Namun sebaliknya jika investor tidak cermat dan tidak tepat dalam memilih perusahaan untuk berinvestasi, maka resiko yang besar akan ditanggung oleh investor sendiri. Resiko nyata yang biasa didapat adalah kerugian akibat nilai jual saham yang turun. Untuk itulah para investor perlu mempelajari dan mempertimbangkan faktor-faktor apa saja yang harus menjadi perhatian dalam membeli suatu saham. Salah satu faktor yang sering digunakan dalam memprediksi harga saham ialah dengan melihat kondisi perusahaan, artinya calon investor perlu memperhitungkan kesehatan keuangan sebuah perusahaan. Hal ini dapat dilihat dari keuntungan yang diperoleholeh perusahaan. Perusahaan yang mempunyai reputasi baik adalah perusahaan yang mampu memberikan dividen secara konstan kepada pemegang saham. Semakin meningkatnya laba yang diterima perusahaan maka tentu akan semakin tinggi pula dividen yang dibayarkan oleh perusahaan kepada pemegang saham.

Salah satu yang dinilai oleh calon investor biasanya berupa kinerja keuangan perusahaan tersebut. Kinerja keuangan perusahaan dapat kita lihat pada laporan keuangan perusahaan dimana laporan keuangan tersebut mencantumkan rasio keuangan. Adapun rasio keuangan tersebut diantaranya adalah rasio likuiditas, rasio leverage, rasio aktivitas, rasio profitabilitas, rasio pertumbuhan dan rasio nilai pasar. Penelitian ini menggunakan Rasio Return On Asset (ROA), Rasio Net Profit Margin (NPM) dan Rasio Earning Per Share (EPS). "Return On Asset mengukur kemampuan perusahaan dalam memanfaatkan aktivanya untuk memperoleh laba "Return On Asset mengukur kemampuan perusahaan dalam memanfaatkan aktivanya untuk memperoleh laba. Rasio ini mengukur tingkat pengembalian investasi yang telah dilakukan oleh perusahaan dengan menggunakan seluruh dana (aktiva) yang dimilikinya. Rasio ini dapat diperbandingkan dengan tingkat bunga bank yang berlaku". Untuk menunjukan pencapaian laba atas seluruh penjualan dapat digunakan net profit margin (NPM). "Rasio net profit margin mengukur laba yang dihasilkan oleh setiap satu penjulalan. Rasio ini memberi gambaran tentang laba untuk para pemegang saham sebagai persentase dari penjualan”. Earning per share adalah jumlah laba yang menjadi hak untuk setiap pemegang satu lembar saham biasa. EPS hanya dihitung untuk saham biasa.

Adapun rumusan permasalahan dalam penelitian ini yaitu: 1) untuk mengetahui pengaruh return on asset (ROA) terhadap harga saham pada perusahaan subsektor perkebunan yang terdaftar di Bursa Efek Jakarta periode tahun 2015-2018, 2) untuk mengetahui pengaruh net profit margin $(N P M)$ terhadap harga saham pada perusahaan subsektor perkebunan yang terdaftar di Bursa Efek 
Jakarta periode tahun 2015-2018,3) untuk mengetahui pengaruh earning per share (EPS) terhadap harga saham pada perusahaan subsektor perkebunan yang terdaftar di Bursa Efek Jakarta periode tahun 2015-2018, dan 4) untuk mengetahui pengaruh return on asset (ROA), net profit margin (NPM) dan earning per share (EPS) terhadap harga saham pada perusahaan subsektor perkebunan yang terdaftar di Bursa Efek Jakarta periode tahun 2015-2018.

\section{TINJAUAN LITERATUR}

\section{Saham}

Saham merupakan salah satu bagian dari pasar modal yang sangat diincar oleh para calon investor. Hal ini disebabkan karena saham dapat memberikan tingkat keuntungan yang menarik. Saham dapat diartikan sebagai tanda penyertaan modal seorang ataupun badan dalam suatu perusahaan.

\section{Harga Saham}

Harga saham adalah harga pada pasar riil dan merupakan harga yang paling mudah ditentukan karena merupakan harga dari suatu saham pada pasar yang sedang berlangsung atau jika pasar ditutup maka harga pasar adalah harga penutupannya. Harga saham adalah harga suatu saham yang terjadi di pasar dan ditentukan oleh permintaan dan penawaran saham yang bersangkutan di pasar modal.

\section{Return On Asset (ROA)}

Return on Asset mengukur kemampuan perusahaan dalam memanfaatkan aktivitasnya untuk memperoleh laba [1]. Return on asset merupakan perbandingan antara laba bersih dengan total aset. ROA berfungsi untuk mengukur efektivitas perusahaan dalam menghasilkan laba dengan memanfaatkan aktiva yang dimilikinya.

\section{Net Profit Margin (NPM)}

Rasio Net Profit Margin disebut juga dengan rasio pendapatan terhadap penjualan. Rasio ini menunjukkan berapa besar persentase laba bersih yang diperoleh dari setiap penjualan. Semakin besar rasio ini, maka dianggap semakin baik kemampuan perusahaan untuk mendapatkan laba yang tinggi. Net Profit Margin merupakan rasio yang digunakan untuk mengukur laba bersih sesudah pajak lalu dibandingkan dengan volume penjulanan. Margin laba yang tinggi lebih disukai karena menunjukkan bahwa perusahaan mendapat hasil yang baik yang melebihi harga pokok penjulan.

\section{Earning Per Share (EPS)}

Pemegang saham biasanya tertarik dengan angka EPS yang dilaporkan perusahaan. Earning per share adalah jumlah laba yang menjadi hak untuk setiap pemegang satu lembar saham biasa. Earning per share atau pendapatan per lembar saham adalah bentuk pemberian keuntungan yang diberikan kepada para pemegang saham dari setiap lembar saham yang dimiliki . Laba per saham merupakan rasio yang menunjukkan bagian laba untuk setiap saham. 


\section{Penelitian Terdahulu}

1. Rosdian Widiawati Watung dan Ventje Ilat (2016). Pengaruh Return on Asset (ROA), Net Profit Margin (NPM) dan Earning Per Share (EPS) Terhadap Harga Saham Pada Perusahaan Perbankan di Bursa Efek Indonesia Periode 2011-2015. Tujuan penelitian ini adalah untuk mengetahui bagaimana Pengaruh Return on Asset (ROA), Net Profit Margin (NPM) dan Earning Per Share (EPS) Terhadap Harga Saham Pada Perusahaan Perbankan di Bursa Efek Indonesia Periode 2011-2015. Penelitian ini dilakukan di Pojok Bursa Efek Indonesia, yang beralamat di Galeri Investasi Bursa Efek Indonesia, Universitas Sam Ratulangi dengan mengambil data sekunder berupa laporan keuangan. Penelitian ini memakan waktu 2 bulan yaitu mulai bulan Mei sampai Juni 2016. Populasi yang digunakan dalam penelitian ini adalah perusahaan perbankan yang telah terdaftar di Bursa Efek Indonesia dari tahun 2011 sampai tahun 2015 sebanyak 7 perusahaan. Sampel yang digunakan dengan menggunakan teknik purposive sampling, yaitu teknik penentuan sampel dengan pertimbangan tertentu. Data yang digunakan dalam penelitian ini adalah data sekunder dimana sumber yang tidak langsung memberikan data kepada pengumpul data. Data sekunder untuk penelitian ini di peroleh dari situs resmi Bursa Efek Indonesia, yaitu www.idx.co.id. Kesimpulan dari penelitian ini adalah Secara parsial Return On Asset (ROA) berpengaruh signifikan terhadap harga saham di Bursa Efek Indonesia Periode 2011-2015 dengan nilai yang didapat yaitu 0,006. Secara parsial, Net Profit Margin (NPM) berpengaruh signifikan terhadap harga saham di Bursa Efek Indonesia Periode 2011-2015 dengan nilai yang didapat yaitu 0,000. Secara parsial, Earning Per Share (EPS) berpengaruh signifikan terhadap harga saham di Bursa Efek Indonesia Periode 2011-2015 dengan nilai yang didapat yaitu 0,000. Kemudian Secara bersama atau simultan, Return On Asset (ROA), Net Profit Margin (NPM) dan Earning Per Share (EPS) berpengaruh signifikan terhadap harga saham di Bursa Efek Indonesia Periode 2011-2015 dengan nilai yang didapat yaitu 0,000.

2. Irsad Andriyanto dan Silvia Khoirunnisa (2018). Pengaruh Return on Asset, Net Profit Margin, dan Earning Per Share Terhadap Harga Saham Perusahaan Rokok Go Public. Penelitian ini bertujuan untuk mengetahui secara empiris pengaruh karakteristik perusahaan yang diproksi dengan return on assets, net profit margin, dan earning per share terhadap harga saham perusahaan rokok yang terdaftar di BEI. Investasi adalah keputusan yang diambil untuk mengalokasikan aset untuk mendapatkan manfaat di masa depan. Penelitian ini menggunakan pendekatan kuantitatif untuk menganalisis sampel perusahaan rokok yang terdaftar di BEI dari tahun 2015 hingga 2017. Data yang diambil dari BEI kemudian dianalisis dengan analisis regresi linier berganda yang didukung oleh SPSS. Hasil penelitian menunjukkan bahwa return on asset dan earning per share tidak berpengaruh signifikan terhadap harga saham. Selain itu, net profit margin adalah variabel yang paling berpengaruh terhadap harga saham. Net profit margin menunjukkan tingkat efisiensi yang tinggi, sehingga menjadi faktor penting yang harus dipertimbangkan oleh perusahaan karena pengaruhnya yang signifikan terhadap harga saham.

3. Carmela Pinky Manoppo (2015). The Influence Of ROA, ROE, ROS, And EPS On Stock Prize. Data Analysis Method is Multiple regression model. It is a regression analysis to explain the relationship between the dependent variable and several independent variables. In the use of regression equation, there are several basic assumptions that have to be met. These assumptions are : normality test, multicollinearity, autocorrelation test, and test 
heteroscedasticity. After regression equation freed from the basic assumption that we then can do hypothesis testing. The variables in this study include the dependent variable and the independent variable. The dependent variable is the variable that has the characteristics in which the size of the variable is influenced by many factors. In other words, the growth of the company depends on a change in one more factor. Whereas the independent variables are variables that can stand on its own without depending on or influenced by other factors. The independent variable used in this study is the Profitability ratios (ROA, ROE, ROS) and Earning Per Share (EPS). The dependent variable used in this study is the insurance company's share price listed on the Stock Exchange. Based on the analysis and discussion that has been stated in the previous chapter, the authors draw some conclusions as follows: ROA, ROE, ROS and EPS have significant influence on Stock Price, Simultaneously. ROA has significant influence on Stock Price. ROE has significant influence on Stock Price. ROS has significant influence on Stock Price. EPS has significant influence on Stock Price.

\section{Hipotesis Penelitian}

Adapun hipotesis dalam penelitian ini adalah sebagai berikut: 1) diduga ada pengaruh signifikan antara Return On Asset (ROA) terhadap Harga Saham pada Perusahaan Subsektor Perkebunan yang terdaftar di Bursa Efek Indonesia periode tahun 2015- 2018.Diduga ada pengaruh signifikan antara Net Profit Margin (NPM) terhadap Harga Saham pada Perusahaan Subsektor Perkebunan yang terdaftar di Bursa Efek Indonesia periode tahun 2015-2018, 2) diduga ada pengaruh signifikan antara Earning Per Share (EPS) terhadap terhadap Harga Saham pada Perusahaan Subsektor Perkebunan yang terdaftar di Bursa Efek Indonesia periode tahun 20152018, 3) diduga ada pengaruh signifikan antara Return on Asset (ROA, Net Profit Margin (NPM) dan Earning Per Share (EPS) terhadap terhadap Harga Saham pada Perusahaan Subsektor Perkebunan yang terdaftar di Bursa Efek Indonesia periode tahun 2015-2018.

\section{METODE PENELITIAN}

\section{Waktu dan Tempat Penelitian}

Penelitian ini dilakukan pada PT Bursa Efek Indonesia Kantor Perwakilan Sumater Selatan di Palembang yang beralamat di jalan Angkatan 45 No.13-14, Demang Lebar Daun, Kec. Ilir Bar. I, Kota Palembang. Waktu penelitian dilakukan selama 6 (enam) dari bulan April sampai dengan September 2020.

\section{Populasi dan Sampel}

Populasi diartikan sebagai seluruh anggota kelompok yang sudah ditentukan karakteristiknya dengan jelas, baik itu kelompok orang, objek, atau kejadian. Populasi dalam penelitian ini adalah 16 perusahaan perkebunan yang tercantum dalam Bursa Efek Indonesia tahun 2015- 2018. Sampel adalah bagian dari jumlah dan karakteristik yang dimiliki oleh populasi tersebut. Bila polulasi besar dan peneliti tidak mungkin mempelajari semua yang ada pada populasi, misalnya karena keterbatasan dana, tenaga dan waktu maka peneliti dapat menggunakan sampel yang diambil dari populasi itu. Jadi sampel dalam penelitian ini adalah sampel jenuh, yakni pengambilan seluruh populasi dijadikan sampel dalam penelitian ini yaitu perusahaan perkebunan yang tercantum dalam Bursa Efek Indonesia tahun 2015-2018 sebanyak 16 perusahaan. Sampel jenuh adalah teknik 
penentuan sampel bila semua anggota populasi digunakan sebagai sampel.

\section{Teknik Pengumpulan Data}

Untuk mengumpulkan data penelitian ini, peneliti menggunakan metode dokumentasi. Dokumentasi merupakan cara pengumpulan data melalui peninggalan tertulis, seperti arsip-arsip dan termasuk juga buku-buku tentang pendapat, teori, dalil atau hukum-hukum, dan lain-lain yang berhubungan dengan masalah penelitian. Dokumentasi tersebut didapat dengan cara mengunduh situs www.idx.com untuk obyek yang diteliti, sehingga dapat diperoleh data ROA, NPM, dan EPS serta Harga Saham serta laporan keuangan dan perkembangannya. Berikut ini adalah instrumen yang dipergunakan untuk tiap-tiap variabel penelitian, yaitu; 1) Variabel Y Harga Saham; 2) Variabel $\mathrm{X}_{1}$ ROA;3) Variabel $\mathrm{X}_{2} \mathrm{NPM}$; dan 4) Variabel $\mathrm{X}_{3}$ EPS.

\section{Uji Asumsi Klasik}

\section{Uji Normalitas}

Uji normalitas dilakukan untuk melihat tingkat kenormalan data yang digunakan, apakah data berdistribusi normal atau tidak [9]. Tingkat kenormalan data sangat penting, karena dengan data yang terdistribusi normal, maka data tersebut dianggap dapat mewakili populasi. Uji normalitas ini digunakan untuk mengetahui kenormalan data, rumus yang digunakan untuk menghitung uji normalitas adalah Chi-Kuadrat. Uji normalitas data menjadi prasyarat pokok dalam analisis parametrik seperti korelasi Pearson, uji perbandingan rata-rata, analisis varian, dan sebagainya, karena data-data yang akan dianalisis parametrik harus terdistribusi normal. Metode uji normalitas yang sering digunakan adalah uji Liliefors dan uji One Sample Kolmogorov Smirnov. Kriteria pengujiannya sebagai berikut: 1) Jika nilai signifikansi $>0,05$, maka data berdistribusi normal dan 2) Jika nilai signifikansi $<0,05$, maka tidak berdistribusi.

\section{Instrumen Penelitian}

Instrumen penelitian merupakan alat bantu yang dapat digunakan oleh seorang peneliti dalam mengumpulkan data-data yang diperlukan. Jumlah instrumen penelitian tergantung pada jumlah variabel penelitian yang telah ditetapkan untuk diteliti. berdistribusi normal. Dalam hal ini data tidak berdistribusi normal.

\section{Uji Multikolinieritas}

Uji Multikolinieritas bertujuan untuk menguji apakah model regresi ditemukan adanya korelasi antar variabel bebas (independen). Model regresi yang baik seharusnya tidak terjadi multikolinearitas. Dilakukan untuk melihat apakah ada korelasi yang erat antar variabel bebas yang akan digunakan dalam suatu regresi.

Jika nilai tolerance lebih besar dari 0,10 maka artinya tidak terjadi multikolinieritas dalam model regresi, sebaliknya jika nilai tolerance lebih kecil dari 0,10 maka artinya terjadi multikolinieritas dalam model regresi. Jika nilai VIF lebih kecil dari 10,00 maka artinya tidak terjadi multikolinieritas dalam regresi, sebaliknya jika nilai VIF lebih besar dari 10,00 maka artinya terjadi multikolinieritas dalam regresi.

\section{Uji Autokorelasi}


Uji asumsi auto korelasi bertujuan untuk menguji apakah dalam suatu model regresi linier ada korelasi antara kesalahan pengganggu pada periode $t$ dengan kesalahan pengganggu pada periode $t$ 1 .

\section{Teknik Analisis Data}

\section{Koefisien Korelasi}

Koefisien korelasi adalah mencari hubungan antara variabel bebas dan variabel terikat dengan menggunakan rumus product moment.

\section{Uji t}

Uji parsial (Uji t) dilakukan untuk membuktikan hipotesis yang dihitung secara terpisah dengan membandingkan $t_{\text {Hitung }}$ dengan $t_{\text {Tabel }}$

\section{Uji Heteroskedastisitas}

Heteroskedastisitas merupakan keadaan dimana variabel pengganggu tidak mempunyai variance yang sama. Model regresi yang baik adalah yang tidak terjadi heteroskedastisitas. ji heteroskedastisitas dalam penelitian menggunakan uji glejser dengan ketentuan yaitu, jika nilai probailitas signifikansinya diatas tingkat kepercayaan 5\% maka dapat disimpulkan model regresi tidak mengandung adanya heteroskedastisitas. Sebaliknya, jika niali probabilitas signifikansinya yang dihasilkan kurang dari 5\% maka ada indikasi terjadi heteroskedastisitas.

berarti tidak diterima atau ditolak.

\section{Regresi Linier Berganda}

Analisis regresi linier berganda adalah pengembangan dari analisis regresi sederhana. Kegunaannya yaitu untuk meramalkan nilai variabel terikat (Y) apabila variabel bebas minimal dua atau lebih [9] Analisis linear berganda digunakan untuk mengetahui pengaruh variabel bebas yaitu Return On Asset (X1), Net Profit Margin (X2) dan Earning Per Share (X3) terhadap variabel terikat yaitu Harga Saham (Y). Untuk menentukan kesamaan dua rata-rata variabel dengan rumus sebagai berikut:

$\mathrm{Y}=\mathrm{a}+\mathrm{b} 1 \mathrm{X} 1+\mathrm{b} 2 \mathrm{X} 2+\mathrm{b} 3 \mathrm{X} 3[9]$

Dimana :

$\mathrm{Y}=$ Harga Saham

$\mathrm{X} 1=$ Return On Asset

X2 = Net Profit Margin

X3 = Earning Per Share $\mathrm{a}=$ Konstanta

$\mathrm{b}=$ Koefisien Regrasi

\section{Koefisien Determinasi}

Koefisien determinasi adalah digunakan untuk mengetahui persentase sumbangan antara variabel bebas (independen) dan variabel terikat (dependen). 


\section{HASIL DAN PEMBAHASAN}

Berikut adalah hasil penelitian ini:

Tabel 1. Hasil Pengolahan Data

\begin{tabular}{|c|c|c|c|}
\hline Pengujian & Indikator & Nilai & Simpulan \\
\hline Uji Normalitas & $\begin{array}{l}\text { One-Sample } \\
\text { Kolmogorov-Smirnov } \\
\text { Test }\end{array}$ & 0,200 & $\begin{array}{l}\text { Data normal } \\
\text { sehingga layak } \\
\text { digunakan untuk } \\
\text { analisis selanjutnya }\end{array}$ \\
\hline \multirow[t]{3}{*}{ Uji MultikolinieritasVIF } & ROA & 4,980 & $\begin{array}{l}\text { Tidak terjadi } \\
\text { multikolinieritas }\end{array}$ \\
\hline & NPM & 3,320 & $\begin{array}{l}\text { Tidak terjadi } \\
\text { multikolinieritas }\end{array}$ \\
\hline & EPS & 2,250 & $\begin{array}{l}\text { Tidak terjadi } \\
\text { multikolinieritas }\end{array}$ \\
\hline Uji Autokorelasi & Durbin-Watson & 1,080 & $\begin{array}{l}\text { Tidak terjadi } \\
\text { autokorelasi }\end{array}$ \\
\hline \multirow[t]{3}{*}{ Uji Heteroskedastisitas } & ROA & 0,002 & $\begin{array}{l}\text { Terjadi } \\
\text { heteroskedastisitas }\end{array}$ \\
\hline & NPM & 0,040 & $\begin{array}{l}\text { Terjadi } \\
\text { heteroskedastisitas }\end{array}$ \\
\hline & EPS & 0,000 & $\begin{array}{l}\text { Terjadi } \\
\text { heteroskedastisitas }\end{array}$ \\
\hline \multirow[t]{4}{*}{ Uji Statistik Deskriptif } & ROA & 8,092 & \\
\hline & NPM & 91,257 & \\
\hline & EPS & 303,824 & \\
\hline & HARGA SAHAM & 3530,010 & \\
\hline
\end{tabular}

\section{Pengaruh Return On Asset Terhadap Harga Saham}

Dari hasil uji t (parsial) pada tabel 4.5 didapat bahwa variabel Return On Asset $\left(\mathrm{X}_{1}\right)$ mempunyai nilai $\mathrm{t}_{\text {hitung }}$ sebesar -0.907 lebih kecil dibandingkan dengan nilai $\mathrm{t}_{\text {tabel }} 2,00030$. Ini menunjukkan bahwa $-0.907<2,00030$ dan Sig. 0,368 > 0,05. Hasil uji hipotesis ini menunjukan bahwa Variabel Return On Asset dalam penelitian ini tidak berpengaruh signifikan terhadap harga saham. Karena investor dan para calon investor menanamkan sahamnya ke setiap perusahaan tidak hanya melihat dari faktor aset saja. Pada umumnya, semakin tinggi nilai ROA maka semakin tinggi pula tinggkat profitabilitas perusahaan tersebut. Hal ini juga merupakan pengertian umum dimana jika perusahaan menguntungkan maka harga sahamnya akan meningkat. Akan tetap pertumbuhan aset tidak selalu menyebabkan nilai laba bersih perusahaan mengalami peningkatan. Jika nilai laba bersih tidak mengalami perubahan atau tetap namun nilai aset mengalami peningkatan, maka nilai ROA akan menurun atau memiliki tingkat yang semakin rendah. Kondisi ini juga menggambarkan bahwa kemampuan perusahaan dalam memperoleh laba dan untuk mengendalikan biaya-biaya operasional dan non operasional sangatlah rendah sehingga kurang berpengaruh terhadap harga saham. Penelitian ini sejalan dengan penelitian Irsad 
Andriyanto dan Silvia Khoirunnisa (2018), menyatakan bahwa rasio Return On Asset tidak berpengaruh positif terhadap harga saham, tapi tidak sejalan dengan penelitian Rosdian Widiawati Watung, Ventje Ilat (2016) dan penelitan Carmela Pinky Manoppo (2015).

\section{Pengaruh Net Profit Margin Terhadap Harga Saham}

Dari hasil uji t (parsial) pada tabel 4.5 menunjukkan bahwa variabel Net Profit Margin $\left(\mathrm{X}_{2}\right)$ mempunyai nilai $t_{\text {hitung }}$ sebesar 0,491 lebih kecil dibandingkan dengan nilai $t_{\text {tabel }} 2,00030$. Ini menunjukkan bahwa 0,228<2,00030 dan Sig. 0,625>0,05. Hasil uji hipotesis menunjukan bahwa Variabel Net Profit Margin dalam penelitian ini tidak berpengaruh signifikan terhadap harga saham. Pada umumnya, semakin tinggi nilai Net Profit Margin maka semakin tinggi pula tinggkat profitabilitas perusahaan tersebut. Hal ini juga merupakan pengertian umum dimana jika perusahaan menguntungkan maka harga sahamnya akan meningkat. Namun pertumbuhan Net Profit Margin tidak selalu menyebabkan nilai laba bersih perusahaan mengalami peningkatan. Jika nilai laba bersih tidak mengalami perubahan, maka nilai Net Profit Margin akan menurun atau memiliki tingkat yang semakin rendah. Hal seperti ini menggambarkan bahwa kemampuan perusahaan dalam memperoleh laba dan untuk mengendalikan penjualan tergolong rendah sehingga kurang berpengaruh terhadap harga saham. Penelitian ini tidak sejalan dengan penelitian Rosdian Widiawati Watung, Ventje Ilat (2018), penelitian Irsad Andriyanto dan Silvia Khoirunnisa (2018) yang menyatakan bahwa Net Profit Margin berpengaruh signifikan terhadap harga saham. Jika perusahaan mempunyai kemampuan menghasilkan keuntungan bersih, maka para investor akan tertarik membeli saham tersebut, hal ini akan menyebabkan harga pasar akan naik.

\section{Pengaruh Earning Per Share Terhadap Harga Saham}

Dari hasil uji t (parsial) pada tabel 4.5 didapati bahwa variabel Earning Per Share $\left(\mathrm{X}_{3}\right)$ mempunyai nilai $t_{\text {hitung }}$ sebesar 6,975 lebih besar dibandingkan dengan nilai $t_{\text {tabel }} 2,00030$. Ini menunjukkan bahwa 6,975 > 2,00030 dan Sig. 0,000 < 0.05. Hasil uji hipotesis menunjukan bahwa Variabel Earning Per Share dalam penelitian ini berpengaruh signifikan terhadap harga saham. Earning Per Share (EPS) atau pendapatan perlembar saham adalah rasio antara laba bersih setelah pajak dengan jumlah lembar saham. Informasi Earning Per Share (EPS) suatu perusahaan menunjukkan laba bersih perusahaan yang siap dibagikan kepada semua pemegang saham perusahaan. Hasil dari penelitian ini sesuai dengan penelitian Rosdian Widiawati Watung, Ventje Ilat (2018), penelitian Irsad Andriyanto (2018) dan penelitian Carmela Pinky Manoppo (2015). Hasil statistik (uji t) menunjukkan bahwa Earning Per Share berpengaruh signifikan terhadap harga saham pada perusahaan Subsektor Perkebunan yang terdaftar di Bursa Efek Indonesia. Dalam memperdagangkan saham laba per saham dapat mempengaruhi harga saham, karena para investor selalu memperhatikan akan pertumbuhan laba per saham perusahaan sehingga dapat mempengaruhi naik turunnya harga saham.

\section{Pengaruh ROA, NPM dan EPS Terhadap Harga Saham}

Berdasarkan uji $\mathrm{F}$ hasil output SPSS menunjukkan bahwa diperoleh nilai $\mathrm{f}_{\text {hitung }}$ sebesar 20,403 dan $\mathrm{f}_{\text {tabel }}$ sebesar 2,76. Jika $\mathrm{f}_{\text {hitung }}>\mathrm{f}_{\text {tabel }}$ maka Ho ditolak dan Ha diterima dan jika $\mathrm{f}_{\text {hitung }}<$ $\mathrm{f}_{\text {tabel }}$ maka Ho diterima dan Ha ditolak. Hasil menunjukkan bahwa 20,403> 2,76 dan juga Sig. $0.000<0.05$ sehingga dapat diketahui bahwa pengaruhnya signifikan. Maka dengan demikian 
dapat diambil kesimpulan bahwa Ho ditolak dan Ha diterima yang artinya terdapat adanya pengaruh yang signifikan Return On Asset, Net Profit Margin dan Earning Per Share terhadap harga saham pada Perusahaan Subsektor Perkebunan yang terdaftar di Bursa Efek Indonesia. Hasil dari penelitian ini sesuai dengan penelitian Rosdian Widiawati Watung, Ventje Ilat (2018), penelitian Irsad Andriyanto (2018) dan penelitian Carmela Pinky Manoppo (2015) yang menyatakan bahwa Return On Asset, Net Profit Margin dan Earning Per Share secara simultan berpengaruh signifikan terhadap harga saham.

\section{KESIMPULAN}

Penelitian ini dilakukan terhadap perusahaan-perusahaan subsektor perkebunan yang terdaftar pada Bursa Efek Indonesia periode tahun 2015-2018, untuk mengetahui pengaruh Return On Asset, Net Profit Margin dan Earning Per Share terhadap harga saham pada Perusahaan Subsektor Perkebunan yang terdaftar di Bursa Efek Indonesia.

Dengan demikian dapat disimpulkan hasil penelitian sebagai berikut:

1) Hasil pengujian hipotesis pertama dari hasil Uji t hasil penelitian menunjukkan bahwa variabel Return On Asset (X1) mempunyai nilai thitung sebesar -0.423 lebih kecil dibandingkan dengan nilai ttabel 2,01537. Ini menunjukkan bahwa $-0.423<2,01537$ dan Sig. $0.016>0.05$. Maka dengan demikian dapat diambil keputusan bahwa Ho diterima dan Ha

ditolak. Artinya tidak terdapat adanya pengaruh signifikan Return On Asset (X1) terhadap harga saham (Y).

2) Hasil pengujian hipotesis kedua dari hasil Uji t hasil penelitian menunjukkan bahwa variabel Net Profit Margin (X2) mempunyai nilai thitung sebesar 0,228 lebih kecil dibandingkan dengan nilai tabel 2,01537. Ini menunjukkan bahwa 0,228<2,01537 dan Sig. $0.821>0.05$. Maka dengan demikian dapat diambil keputusan bahwa Ho diterima dan Ha ditolak. Artinya tidak terdapat adanya pengaruh signifikan Net Profit Margin (X1) terhadap harga saham (Y).

3) Hasil pengujian hipotesis ketiga menunjukkan bahwa bahwa variabel Earning Per Share (X3) mempunyai nilai thitung sebesar 5,483 lebih besar dibandingkan dengan nilai ttabel sebesar 2,01537. Ini menunjukkan bahwa 5,483 > 2,01537 dan Sig. 0,000 < 0.05. Maka dengan demikian dapat diambil keputusan bahwa Ho ditolak dan Ha diterima. Artinya terdapat adanya pengaruh signifikan Earning Per Share (X3) terhadap harga saham (Y).

4) Hasil pengujian hipotesis keempat menunjukkan bahwa di peroleh nilai fhitung sebesar 12.857 dan ftabel sebesar 2,81. Jika fhitung > ftabel maka Ho ditolak dan Ha diterima dan jika fhitung < ftabel maka Ho diterima dan Ha ditolak. Hasil menunjukkan bahwa 12.857>2,812 dan juga Sig. $0.000<0.05$ sehingga dapat diketahui bahwa pengaruhnya signifikan. Maka dengan demikian dapat diambil kesimpulan bahwa Ho ditolak dan Ha diterima yang artinya terdapat adanya pengaruh yang signifikan Return On Asset, Net Profit Margin dan Earning Per Share terhadap Harga Saham pada Perusahaan Subsektor Perkebunan yang terdaftar di Bursa Efek Indonesia.

\section{DAFTAR PUSTAKA}

D. Prastowo, Analisi Laporan Keuangan Konsep dan Aplikasi, 3rd ed. Yogyakarta: Unit Penerbit dan Percetakan STIM YKPN, 2015. 
M. Azis, Manajemen Investasi Fundamental, Teknikal, Perilaku Investor dan Return Saham, 1st ed. Yogyakarta: Deepublish, 2015.

M. Ukhriyawati C. F., \& Pratiwi, "Volume 5 No.2 Tahun 2018 Print ISSN 25031546," J. Equilibira, vol. 5, no. 2, pp. 1-9, 2018.

P. I. Sari, "Analisis Harga Saham Dengan Earning Per Share (EPS) dan Return On Equity (ROE) pada Sektor Properti Real Estate yang Terdaftar di Bursa Efek Indonesia," Universitas Muhammadiyah Sumatera Utara, 2019.

V. W. Sujarwei, Analisi Laporan Keuangan Teori, Aplikasi dan Hasil Penelitian, 1st ed. Yogyakarta: Pustaka Baru Press, 2019.

I. Fahmi, Pengantar Manajemen Keuangan Teori dan Soal Jawab, 3rd ed. Bandung: Alfabeta, 2014.

I. Fahmi, Analisi Kinerja Keuangan, 4th ed. Bandung: Alfabeta, 2017.

Sugiyono, Metode Penelitian Kuantitatif,Kualitatif dan R\&D, 28th ed. Bandung: Alfabeta, 2018.

H. Usman, Pengantar Statistik. Jakarta: Bumi Aksara, 2012.

S. Raharjo, "Uji Multikolinearitas dengan Melihat Nilai Tolerance dan VIF SPSS,"2019. https://www.spssindonesia.com/201 4/02/uji-multikolonieritas-dengan- melihat.html.

Sugiyono, Metode Penelitian Kuantitatif, I. Bandung: Alfabeta, 2018. 